\title{
The Violent Art: Caricatures of Conflict in Germany
}

\author{
Mark Hewitson, University College London
}

In the visualization of violence, cartoons played a unique part in the modern era precisely because they made no claim to realism. Although they referred to a credible and tangible reality, caricatures relied on a recognition of the difference between 'likeness' and 'equivalence' for their effect, in Ernst Gombrich's formulation. ${ }^{1}$ The purpose of satirical cartoons was to compare one object to another, with the objects usually different in most other respects, in order to challenge, subvert or undermine it. In this way, the pompous, powerful butts of cartoons' jokes could be likened to unflattering objects and placed in incongruous or degrading situations. In the notorious 'Palestine' edition of Simplicissimus in 1898, Thomas Theodor Heine showed how the technique worked, depicting Kaiser Wilhelm II - on a visit to the Ottoman Empire - as an angel and as a preposterous medieval crusader. ${ }^{2}$ The imperial authorities imprisoned the cartoonist for lèse-majesté, fearing ridicule in a mass medium. 3 Yet it was difficult to ban caricature outright, as the National Socialists' attempt to set up their own satirical publications (Die Brennessel and Die Zeitlupe), while continuing to publish established magazines such as Simplicissimus and Kladderadatsch, demonstrated.4 'To the great mass of his countrymen', the humourist was 'only a voice which expresses, with wit or passion, what these people think and feel and have tried to express', wrote the editor of Die Zukunft, Maximilian Harden: 'No other sort of publication can have such an effect on public opinion as the illustrated satirical magazine, which appeals to the most brilliant and to the simplest mind and, with its scornful challenge and raucous laughter, attracts attention everywhere.'5 Unlike in traditional theatre and painting and in the new traditions of photography and film, where realism was firmly established or appeared to be connected to the medium itself, caricature permitted artists to imagine degradation and incongruity, with cartoonists developing their unrealistic and distorting methods from the study of physiognomy and the facial expression of emotions, which were rendered by simple lines - only some of which were seized upon - and by the exaggeration of specific characteristics. This exaggeration of details, which was fundamental to caricature, revealed graphically how cartoonists perceived the social and political world in which they lived.

Modern wars reinforced - or created, as many contemporaries claimed in 1870 and 1914 - a sense of national community in Germany, requiring greater 
conformity of citizens and increasing their awareness of outsiders and foreigners. Values which were supposedly shared had come to legitimate each of the main conflicts: 'German freedom' and Bildung in the wars of unification; 'German heroism', the ideas of 1914 (rather than those of 1789) and of 'civilization' in the First World War; and a Nazi Volksgemeinschaft and the defence of Europe against the 'barbarism' of the East and of Bolshevism in the Second World War. ${ }^{6}$ Ridicule could help to guarantee obedience and self-sacrifice by ostracizing dissenters, giving solace to victims and maintaining a distinction between 'us' and 'them' through stereotypes and revelations about the humiliating and criminal acts of the enemy. 7 Stories of war atrocities, frequently referred to in cartoons, were an extreme instance of such demonization, but less obtrusive mockery was more common and, arguably, more effective. ${ }^{8}$ Such mockery sought to discredit both internal and external enemies, criticizing hypocrites, pacifists, shirkers, profiteers, saboteurs, deserters and outsiders. 9 Cartoons, it can be held, established the boundary between such 'traitors' and 'patriots' with greater immediacy and impact than did stories in the press, novels, or plays. ${ }^{10}$ However, they also revealed the porous and temporary character of the boundary as the targets and images of the caricaturists changed. Satirical support for the war effort - or 'the deliberate use of the comic for the purposes of attack', in Peter Berger's definition of satire - could easily and rapidly turn against the authorities responsible for the conduct and continuation of the conflict. ${ }^{11}$ Ludwig Thoma, the editor-in-chief of Simplicissimus in 1914, had been convinced by his colleagues to keep on publishing the magazine during wartime, even though foreign powers' alleged attack on the Kaiserreich, which was facing a 'war of defence ... for its own existence', seemed to leave 'no room and no further task for a satirical paper of opposition to the ruling powers in Germany'.12 This self-imposed restriction could easily be reversed, it appears Here, I explore how the boundaries of an unstable national community in wartime were consolidated and subverted by the humour of caricature. ${ }^{13}$

\section{Acts of aggression}

Caricature, in a Freudian sense, allows the bypassing of social restrictions and personal inhibitions in order to satisfy aggressive or sexual instincts. ${ }^{14} \mathrm{By}$ mocking an enemy, 'we achieve in a roundabout way the enjoyment of overcoming him', wrote the psychoanalyst. 15 'Tendentious' jokes, which were central to satire, rested on the exaggeration of particular personality traits, actions or forms of behaviour in a fashion that would have caused offence in other contexts. ${ }^{16}$ Representations of bullying, dismemberment and killing were commonplace in caricature, despite being tabooed in ordinary life. ${ }^{17}$ Accordingly, 
one cartoon ('Kultur und ...') published in Kladderadatsch in October 1914, before the slaughter on the Western Front became public knowledge, had already 'imagined' the 'cultural' consequences of the war: namely a destroyed hospital, bound and filleted corpses scattered over blood-soaked ground, a baby tossed from its cot and a beheaded mother skewered on a sword. ${ }^{18}$ These images from the start of the First World War are just as gruesome as those produced by the National Socialists in the last throes of the Second World War (for example 'Sewastopol', 'Das Verbrechen an Europa' and 'Die Drohung aus der Steppe', which appeared in Kladderadatsch in 1942-3).19 Little account was taken of 'respectable' sensibilities. Few, if any, complaints seem to have been made.

The violence of such cartoons was expressed - and made more palatable by different means, avoiding censure even when the acts of aggression depicted were being committed by Germans rather than their foes. Enemies were stripped of their humanity. During the 'wars of liberation', they had literally been demonized, or at least shown to be in league with the Devil. ${ }^{20}$ In one popular broadsheet which gained international renown, Napoleon was represented as a child in the Devil's arms, swaddled in the tricolore. ${ }^{21}$ 'This is my beloved son, in whom I am well pleased,' ran the caption, repeating Matthew 3: 17. Such biblical references appear to have been less frequent during the wars of unification and very rare in the twentieth century. By this time, enemies were much more regularly depicted as animals or animated corpses. The practice of reducing countries to animals, via stereotypes which supposedly captured their essence, had been established in the early modern period but had become much more widespread in the course of the nineteenth century, with the emergence of nation states and their role in the Concert of Europe and imperialism..$^{22}$ By the late nineteenth century, 'Slav', Asian and African nationalities were shown as monkeys or vermin, making violence and repulsion more acceptable and justifiable responses. ${ }^{23}$ With some exceptions, such as when 'England' was depicted as a vampire bat or a spider, the Great Powers were usually transformed into less repulsive or inferior animals: Russia was portrayed as a bear, crude and dirty but potentially powerful; Britain as a lion, magnificent but falsely proud; and France as a cockerel, strutting and crowing bombastically and conceitedly. ${ }^{24}$ Generally, the powers were still given human 'characters', sometimes risible, like a chinless English country gent or a worn-out Parisian prostitute, at other times formidable, like an imperious, urbane British aristocrat or an alluring, unattainable French seductress, for instance. ${ }^{25}$ Dehumanization in these circumstances more often took the form of contorting a familiar character's features or removing its flesh to reveal the muscle tissue and bone beneath. In 'Die Entente-Danae's und der Goldregen' (1915), 'Die deutsche Antwortnote' 
(1915), 'Der Kampfverlängerer' (1941), 'Der plutokratisch-bolschewistischer Treuschwur' (1941), 'Der Verräter Europas' (1942), 'Die neuen Demokraten' (1942), 'Die nächste Generation' (1943) and 'Einladung zur Invasion' (1944), John Bull - or Winston Churchill as John Bull - was shown with skin hanging off his face, closely resembling an ape. ${ }^{26}$ One cartoon from the First World War, entitled 'Pariser Bluthochzeit' (1917), showed the Reverend John Bull as a goutridden pastor, presiding over the wedding of an emaciated Marianne and Georges Clemenceau's corpse, which was lusting after the republican symbol of France with his eyes bulging and his moustache still in place. ${ }^{27}$ Confronted by these premonitions of death and disfigurement, readers naturally recoiled from and reacted against their enemies. German acts of aggression against such a menace rarely risked losing readers' sympathy.

Cartoons could envisage acts of violence with impunity because they were not believed to be real. Whereas lithographs, photographs and newsreels seemed to reveal actual events in an unmediated fashion, caricature functioned by means of exaggeration. Thus, although Simplicissimus was famous for effecting a transition from situational and literary humour, which relied to a greater extent on the combination of picture, text and allusion, towards glossy or grainy photograph-like imagery, which quickly became the norm during the early twentieth century, readers were never in doubt that the periodical's cartoons were fantasies. When the publication first appeared in 1896, it had immediately caused offence through its graphic examination of religious and moral taboos, provoking - in Ludwig Thoma's recollection - Catholic and Protestant priests to call for the 'outlawing' of the business and for 'ministers, police chiefs, public prosecutors and even judges' not to worry about 'circumventing or contravening legal stipulations in order to suppress or damage the hated or, at least, purportedly nefarious satirical magazine (Witzblatt).'28 Simplicissimus, wrote the owner Albert Langen in the seventh issue, was held to be 'revolutionary' and 'socialist' by some, and 'pornographic, shameless [and] immoral' by others, as they flicked through the pictures 'with a lustful gaze'.29 The periodical deliberately contravened Kladderadatsch's declaration, in a celebration of its fiftieth anniversary in 1898, that it would 'reject any equivocal joking or flippant remarks on decency and morals' and that, 'moreover, [the editors] avoid any seductive pictures of nudity or of partial nudity, such as one finds in foreign magazines.'30 Simplicissimus seems to have broken such unspoken rules. However, it was obvious to most contemporary observers, even to critics of the Munich publication, that any offending images did not reproduce reality but, instead, commented on it. Indeed, in the playwright Gerhart Hauptmann's opinion, it was precisely this criticism which opponents found offensive, not the images 
themselves: 'Simplicissimus is the sharpest and most ruthless satirical force in Germany. All the merits and shortcomings of humorous satire manifest themselves in this art magazine. Its existence is in no way a sign of the sickness of our public life. Rather, this could be the sensitivity of those who are targeted by its admittedly infernal pranks in effigy.' ${ }^{11}$ Caricature created symbolic embodiments - or effigies - of opponents, which could be manipulated and lampooned in an imaginary world. Violence here could be countenanced as an expression of frustration or a reaction to oppression rather than a real act with terrible consequences.

The idea that caricaturists were guilty of acts of aggression, causing terror, was preposterous, contended Simplicissimus during the critical prosecution of its 'Palestine' issue in 1898. In a subsequent issue, Eduard Thöny - who had himself gone underground - showed Langen, Thomas Theodor Heine and Frank Wedekind, the author of a biting poem about Wilhelm II's trip to the Holy Land, as 'the latest acquisitions for the chamber of horrors', exhibited in all their bourgeois frightfulness - top hats, pince-nez and stiff collars -with their name plaques prominently displayed. ${ }^{32}$ The cartoons were merely jokes, not to be taken seriously, implied the magazine, ridiculing imperial censorship and police interference in 'Wie ich meine nächste Zeichnung machen würde', which envisaged Heine drawing in prison, surrounded by six policemen and with a prosecutor peering over his shoulder. 33 Even when directed against the ultimate repository of authority at home, literary and visual acts of aggression should be granted immunity from prosecution and control, suggested the contributors to Simplicissimus. Initially, the authorities themselves disagreed, imprisoning Heine and pursuing Langen and Wedekind, yet they revised their opinion before the First World War, pardoning the editor in 1903 and commuting all later jail sentences save one - Thoma's six-week incarceration in 1906 - to fines. By 1914 few, if any, caricaturists seem to have been worried about being prosecuted for the aggressiveness of their imagery. 34 On the contrary, they were concerned that the usual targets of their aggression - what Thoma referred to as 'the consequences of an operatically conducted politics' - had disappeared as a result of the changed circumstances of war. 35 When Thoma proposed shutting down the magazine for this reason, Heine replied that the conflict was an opportunity to redirect the fire of their 'endless lieutenant and Junker jokes' towards the enemies of the fatherland. ${ }^{6}$ The implication was that the violence of such tendentious jokes would find new sources of inspiration. Since such aggression had been accepted by the public in the cut and thrust of domestic politics, it was unlikely to be criticized when deployed against foreign targets. In 1939 the transition from peace to war was different, because the National Socialists had 
prohibited the satirizing of domestic authorities, but the expression and representation of violence - whether targeting internal or external enemies of the Reich - were notable for their continuity.

Whether contemporaries found such cartoons funny is more difficult to assess. In Freud's opinion, much of the pleasure of tendentious jokes derived from the satisfaction of aggressive or sexual instincts which were otherwise inhibited. The fact that the butt of a hostile joke felt inferior or contemptible heightened the pleasure of the joke-teller and that of his audience. 37 ' Here, it is finally possible to comprehend what the joke achieves in the service of its tendency (Tendenz)', wrote Freud.

It facilitates the satisfaction of an urge (whether lustful or hostile) against an obstacle which is standing in its way, it passes by this obstacle and thus creates desire from a source of desire which has become inaccessible because of the obstacle. 38

The pleasure of jokes (and, therefore, of satire and caricature) came from the satisfaction of instincts by overcoming inhibitions about both sex and violence. In wartime, taboos on aggression against enemies had already been breached; by the same token, the pleasure of breaking such taboos had diminished.

\section{Enmity and solidarity}

Like Freud (and Henri Bergson) and unlike many other anthropologists, Mary Douglas has argued that jokes, laughter and the comic play an important part in the social order, not least as 'an image of the relaxation of conscious control in favour of the unconscious'. 39 For the British anthropologist, the apparently uncontrolled statements of satirists are only to be understood within dominant, well-entrenched structures of power and belief. 'Structural analysis does not work by reducing all symbols to one or two of their number,' she insists. 'Rather, it requires an abstract statement of the patterned relations of all the symbols to one another.'40 Jokes are not isolated incidents of rebellion; they form part of a symbolic continuum which itself is closely connected to an existing - as well as an imagined - social order. 'A joke is seen and allowed when it offers a symbolic pattern of a social pattern occurring at the same time,' Douglas continues. 'A joke is a play upon form. It brings into relation disparate elements in such a way that one accepted pattern is challenged by the appearance of another which in some way was hidden in the first.'41 The spontaneity of jokes and cartoons is to be understood in this sense: they comment on existing relations of power and forms of interaction in a manner that is acceptable to the social group in which they are disseminated, using largely familiar and socially patterned constellations of symbols. Consequently, humour is distinguishable from the breaking of taboos, 
serving as a point of articulation between one state of affairs - a stage of life, political order or social group - and another, rather than constituting a genuine threat to most aspects of the status quo. A joke subverts but does not fully undermine: 'the strength of its attack is entirely restricted by the consensus on which it depends for recognition.' 42

War removed many of the usual sources of satire.43 Internal authorities such as Otto von Bismarck, Wilhelm II, the army, ministers and politicians had previously been the butt of jokes and the subject matter of caricature. Cartoonists had delighted in placing them in incongruous situations, comparing them with unexpected and absurd figures and objects, and exaggerating and exposing their pomposity and hypocrisy, degrading them through reference to their character traits, bodily defects and public pronouncements, which were likened to those of lowly or elevated 'types', 'personalities' and 'things'. In the era of the constitutional conflict between Bismarck and the Prussian lower chamber, for instance, the Chancellor was depicted by Kladderadatsch as a muscle-bound, centurion-like American tightrope walker who had just crossed Niagara Falls. Unfortunately, the Prussian 'Blondin, der Held vom Niagara' (Blondin, the Hero of Niagara), in the caricature's title, was forced to carry the black, faceless character of 'conflict' on his shoulders, 'who is much heavier than he is himself', as he made his way on the rope from the small burning building of 1865 to that of 1866.44 The dignity and strength of the 'heroic' Chancellor's struggle was subverted by his vainglorious, balletic pose; the muscular, naked flesh of his legs, protruding coquettishly from his centurion's 'skirt'; and the purely trivial entertainment of his undertaking. During the Austro-Prussian War, which broke out a year later, Bismarck was shown in apparently similar circumstances in the cartoon 'Eine Hercules-Arbeit in acht Tagen'. 45 The comparison seems to offer the possibility of contrasting the muscularity, nakedness and activity of the Greek hero with the trivial pursuit of the Prussian Chancellor. Instead, Bismarck was portrayed in his habitual military garb, a youthful but calm figure, smoking a pipe as he swept out the hay - expelled states such as Saxony, Baden, Württemberg, Bavaria and Austria - from the Augean stables of the German Confederation. The butt of the joke was no longer the Chancellor but Prussia's enemies and the external body of the old German Bund.

A similar transition could be observed in 1870 and 1914. Before the First World War, for example, Wilhelm II had been widely ridiculed, as Freud had noted in a well-known joke about 'Serenissimus' (the Kaiser's nickname): 'As in the case when Serenissimus asks a stranger, whose resemblance to his own person was striking: "Was his mother in the royal residence on any occasion?" And the robust reply comes: "No, but my father was." 46 The joke illustrates how 
even the monarch, despite the legal protection which he enjoyed in the form of lèse-majesté, could be mocked during the imperial era.

The person asked would certainly want to knock down the rude person who has dared to sully the memory of his beloved mother through such an allusion, but the rude one is Serenissimus, whom one cannot knock down, whom one cannot insult, unless one wants to pay for revenge with one's whole existence. It is therefore a case of silently absorbing the insult, but luckily the joke shows how it can be made to count ... The prohibition of abuse or of an insulting retort as a result of external circumstances is so common that tendentious jokes are especially preferred to facilitate aggression towards, or criticism of, those occupying high positions who claim authority. The joke then constitutes an act of revolt against such authority, an emancipation from the pressure which it exerts. The appeal of caricature resides in this aspect: we laugh about it, even when it is ill-advised, simply because we count revolt against authority as a service. ${ }^{47}$

In caricatures, Wilhelm II was regularly represented in peacetime as a grandiose buffoon, in romantic or medallioned military attire; he was mocked by Maximilian Harden, the editor of Die Zukunft, as 'Filmhelm' or the 'Reisekaiser' because of his predilection for publicity-seeking exotic travel. $4^{8}$ During the First World War, however, the Kaiser's firmness of purpose, his joviality and his simplicity were celebrated, as in the portrayal of his declaration 'I know of no more parties, I know only Germans', standing on a simple dais between burghers and workers, their arms raised in unity.49 A parallel shift occurred in caricatures of Hitler before and after 1933, from Simplicissimus's incongruous comparison in February 1933 of a knock-kneed, simple-minded Hitler and the Germanic hero Hermann - whose plinth in the Teutoburger Wald Hitler now occupied - to Kladderadatsch's flattering vision in April of the Nazi leader as a Teutonic knight lancing a Jewish devil, in 'The Struggle for the Worker's Soul'.50

The perceived existential menace of war caused a rapprochement of structure and community, with authorities protected from attack in the name of a united struggle against an external foe. Attempts to reconstruct hierarchies of power in an international arena, akin to those of pre-war domestic politics, proved unconvincing. The established techniques of caricature - imitation, exaggeration, incongruity and degradation - were blunted by the unfamiliarity, haziness and distance of the international order. The leaders of foreign states and international structures of power were arguably less well known, depriving satirists of essential sources of humour - knowledge, proximity, inequality and oppression. During the 1860 os and 1870 , heads of state, ministers and politicians in Austria and France were frequently presented as the dramatis personae in a play, with characters quite similar to those given to domestic politicians in 
parallel cartoons. National figures such as Marianne, John Bull, Germania and Michel were prominent but were rarely used to demonize the enemy, and they often intermingled with statesmen. ${ }^{11}$ Thus, 'Die ganze Bande', published in Kladderadatsch in August 1870, arranged the full group of Germany's enemies in France, who had 'wanted to overrun Germany, "marching at the head of civilization"!'52 It combined revolutionary characters representing the civil guard, symbols of Catholicism and molesting, wild-eyed colonial troops with politicians such as Adolphe Granier de Cassagnac and the Emperor and members of his entourage. Although some of the portrayals of the Franco-German War of 1870-1 experimented with demonic stereotypes, such as 'Glück auf zum neuen Jahr!', showing national characters circling a cauldron labelled 'Germany's fall', most cartoons maintained the impression of a shared European civilization, in which Napoleon III was a supposedly powerful but ridiculous upstart.53 'In der vorletzten Stunde' imagined a Prussian infantryman looking at the theatre of the Second Empire on the far bank of the Rhine, with the assembled French characters baying at a bemused-looking eagle in Germany: Louis Bonaparte, dressed as a Roman emperor with bare legs and an imperial helmet, was shown descending from a curtained throne, resembling a stage, and drawing his sword in melodramatic aggression.54 Such a deflating comparison of the French leader with a Roman emperor amidst a panoply of other protagonists was typical of caricatures of domestic politics and relied on readers' familiarity with French politics and their belief in an international hierarchy of power, in which Napoleon III was resented for his unjustified position and actions in much the same way a Prussian statesman or general was. Before, during and after the First World War, cartoonists made sporadic efforts to re-establish the idea of an unfair international order, yet foreign leaders were not frequently portrayed in the same way as were the members of domestic elites during peacetime.55 In Douglas's terms, with the demise of the Concert of Europe and a cosmopolitan European culture, it seemed increasingly difficult for social and symbolic patterns to coincide across national borders.

In both the First and Second World Wars, cartoons increasingly came to rely on the distinction between insiders and outsiders, and on stereotypes of the 'other'. Jokes seem to have lost much of their subversive character, serving mainly to ensure the nation's solidarity behind the war effort. 'As soon as there was war, there was nothing other than the fate of our own country,' wrote Thoma about 1914 in his memoirs. 'Feeling international, being just to the most dangerous enemies was never in my nature, and it was not hard for me to desire their downfall and to want a complete victory for Germany.'56 Enemies were powerful and often despised, but the system of states, by the twentieth century, 
was not a social order in Douglas's sense. Nation states appeared - to many contemporaries - to exist in a form of international anarchy, instead of in familiar sets of relationships within a hierarchy. Thus, although the symbols which were used to describe foreign powers became increasingly formulaic, corresponding to stereotypes of the enemy, the conditions in which they were used were volatile and threatened to destabilize the symbolic order. The boundary between humour and abomination was reduced in modern wars, yet taboos on abominable acts against foes seem to have been removed. In other words, unacceptable satirizing of domestic targets, in a period of existential threat, could provoke a reaction of 'social offence' more typical of Douglas's 'primitive societies'; the ridiculing of foreign opponents, by contrast, became more and more extreme, breaking taboos on the depiction of violence with apparent impunity.

Some of the cartoons are so shocking that it is difficult to believe that they were also found to be funny. The front page of Kladderadatsch on 20 September 1914, for example, showed Théophile Delcassé, Count Alexander Iswolsky and Sir Edward Grey hanging from nooses, the last with his neck broken and with his eyes bulging sickeningly. ${ }^{7}$ 'You whose acts stink to the high heavens - what will become of you - when you lay down your weapons?' ran the caption. Such cartoons used many of the same techniques as peacetime caricatures of domestic politics, contrasting words and deeds or juxtaposing pomposity and absurdity in order to expose hypocrisy and arrogance, but the figures - since they embodied the national characters of distant enemies rather than the half-tolerated foibles of particular individuals - remained stereotypical and dangerous, blocking some of the sources of laughter by their menacing and generic nature. Thus, 'Vorwärts christliche Soldaten!', which appeared on 21 March 1943, subverted some of the symbols summoned by the British hymn, including a lunatic bishop rolling his eyes and singing too vigorously through the asymmetrical orifice of his mouth amidst the rolling flesh of his double chin, juxtaposed ironically with the massed ranks of singing and marching British soldiers; some decadent but chiselled Australian and Canadian troops and other, beast-like African ones, followed by a giant, unshaven, pock-marked Jewish Bolshevik as an angel, blood dripping thickly from his raised hands..$^{8}$ In a trope which had been popular since the deployment of French colonial troops in 1870-1, the cartoonist suggested that it was preposterous to claim that such barbaric forces fought for the good of Christianity and civilization, implying - in a National Socialist variation on the theme - that they had been orchestrated by Jews. The butts of the joke had been exposed, but they remained - in all their relentless insanity - terrifying rather than amusing. 
Such black humour could be seen as the reverse of Douglas's 'tilting of uncontrol against control'.59 In this sense, it constituted a desperate attempt to restore order or solidarity in the face of fear and aggression. Thus, although Freud's obstacles to aggressive instincts seemed to have been removed, however briefly, the normal mechanisms for creating laughter - or humour - from such a release were no longer available. Many of the jokes of wartime cartoons were neither funny nor containable, circumstances that create unacknowledged difficulties for Douglas's structuralist anthropology, with its assumptions about the congruence of social and symbolic patterns. In contrast to Freud, the British anthropologist found it hard to conceive of jokes as an eruptive force, with a deep and complicated personal history and with unpredictable social and cultural consequences.

\section{Norms and the abnormality of war}

Not least because they examine larger groups and institutions, sociologists have proved less willing than anthropologists to assume that the social and symbolic orders coincide and that humour has a ritual - or anti-ritual - function of social integration. To Michael Billig, a Freudian sociologist working in the tradition of frame analysis and symbolic interactionism, ridicule, as one of the principal forms of socialization, is at once fissiparous and binding. ${ }^{60}$ In societies where the coercive imposition of norms takes place only in extremis, via legal prosecution, persuasion and self-discipline are more significant in the perpetuation of binding social rules and rituals, meaning that ridicule often helps to prevent the contravention of norms, threatening offenders with exclusion from the group. ${ }^{61}$ Humans are not simply 'laughing animals' but are laughed at, with laughter a social activity which necessarily refers to what it is not, or what Billig terms 'unlaughter'. ${ }^{62}$ 'Laughter is, to many men, worse than death', wrote Sydney Smith. 'There are very few who would not rather be hated than be laughed at.'63 The enforcement of social norms in Billig's account is uncertain, partly because of the specificity of humour, which could be 'funny on one side of the Pyrenees' following Blaise Pascal's observation - and 'not on the other side', and partly because of the dual nature of jokes, which always refer to what they are not, sometimes in opaque ways, and which derive - the sociologist agrees with Freud - from unconscious sources. 64 In spite of being 'in need of an echo' or social approval, they also provoke a 'momentary anaesthesia of the heart', in Bergson's metaphor, freeing individuals briefly from the social necessity of taking others' feelings into consideration. 65 As a result of the propinquity of laughter and unlaughter, inclusion and exclusion, humour is notoriously unpredictable. In the words of one commentator, humour 'haunts' society. ${ }^{66}$ 
In wartime the usual relationship between an internal enforcement of norms and an external allusion to otherness - with the former much more common and, arguably, more decisive than the latter - was reversed, with demonization of enemies playing a predominant role in the caricature of satirical magazines. Nonetheless, commentary on domestic codes of conduct and actual behaviour continued to occur. Initially, such policing of norms was positive, with regular depictions of the fatherland and the unity of the nation. The most salient example of a united population was the ‘Burgfrieden’ of the First World War, but there were similar references in 1870 and 1939: 'We have managed to free our home of the old conflicts; the whole of Germany fulfilled the word of the Kaiser: "I know no parties," ran the caption of 'Burgfrieden' (1915) in the liberal periodical Lustige Blätter; simple soldiers 'are the core of our own army, the immovable steel columns, worlds apart from the sentiments of the coward', even though they yearned for peace, declared 'Ausrückende Landwehr' (1915) in the Social Democratic Der Wahre Jacob. ${ }^{67}$ The land being defended was typically conceived of as a rustic embodiment of national 'virtues'. 'Ostpreussen!', for example, which appeared in Ulk in 1914, showed a sturdy Prussian female peasant ploughing a fertile field at sunrise, proving that 'German soil' was 'free', with 'the man on the battlefield, the woman in the field'. ${ }^{68}$ Such images were associated with military affairs, including the 'Treatment of Prisoners' (1916) in 'barbaric Germany', which imagined a plentiful, simple meal being offered to a French prisoner of war by a peasant woman in a wheat field, and they extended to the later depiction of peace, with 'Der Hochtourist' (1916) imagining Mars on top of a vertiginous, dark mountain, in contrast to the sun-bathed 'Hotel Weltfrieden' below, standing beside a fruit-laden apple tree in a grassy meadow. 69 In Nazi Germany, such references to peasant simplicity and fortitude, now in a more obviously racial form, constituted the principal representation of the home front during the Second World War. Accordingly, 'Volk im Einsatz' juxtaposed a steelhelmed soldier and a resolute, square-jawed wife, whose headscarf and healthy complexion recalled the fields of the countryside despite the symbols of industry (cogs) and industrial warfare (a machine-gun and aeroplane) framing the picture. $7^{70}$ These images, which were reworked throughout the Nazi era, were deployed in a multitude of contexts during the war itself. ${ }^{71}$ They were rarely as stable or unchallengeable as they purported to be, however, not least because the industrialization, urbanity and plurality of German society had become increasingly difficult to deny.

The policing and enforcement of communal domestic norms during wartime carried great risks, with the identification of internal enemies exposing divisions, discontentment and resistance in the population and threatening to 
extend criticism and ridicule to the authorities themselves. ${ }^{22}$ During the First World War, profiteers and shirkers were lambasted in cartoons such as 'Das Gold auf die Reichsbank!' (1914), which portrayed a fat, slipper-wearing, bourgeois grandee refusing a nurse's request for charity on the grounds that 'our kind are sacrificing enough for the fatherland ... I lose enough interest on my buried gold', and 'Das Gänseliesel' (1916), which showed an impoverished peasant girl in 1913 becoming a corpulent, garishly dressed princess by the autumn of 1916.73 Similarly, strikers were displayed as being 'in the service of England' (1917), working 'for the pleasure of the Entente' (1918); the press ('Die Annexionslustigen', 1918), women's rights campaigners ('Frauenarbeit Frauenfortschritt', 1915) and politicians of different parties were all lampooned for their selfishness and lack of responsibility. 74 Yet such satire could quickly be directed at those in power, from German diplomats (who were shown rejoicing 'We are taken care of' - since the Entente was demanding that they - in their full chinless ineffectualness - be returned to their posts) to 'Prussian feudal conservatives' (who were depicted in armour, sporting 'the new Prussian style of moustache', labelled 'democracy'). 75 The Centre Party leader, parliamentary reformer and later Weimar minister Matthias Erzberger was ridiculed with particular vehemence: in 1917 he was ingloriously compared to a soldier returning home, regretting - in a Bavarian accent - to his 'little woman' that he had not been made Chancellor 'this time', and in December 1918 he was exposed by the 'return home of Odysseus' in the form of a young German soldier, caught fawning over Germania along with Friedrich Ebert, Kurt Eisner and other craven courtier-politicians..$^{76}$ Such portraits of domestic targets of satire resembled those of foreign enemies, whether feckless British aristocrats, cowardly bourgeois French leaders such as Raymond Poincaré, or heartless, feasting British royalty. 77 During the Second World War, National Socialists attempted to avoid this type of comparison, which sometimes seemed to equate external and internal foes (including those in positions of authority), by blaming Jews for domestic unrest and sabotage and by concentrating to a greater extent on the domestic woes of their enemies. However, the tropes which were repeated about the USSR and 'England' - concerning selfish plutocrats and a suffering people, demagogic socialists, arrogant aristocrats, a lustful and avaricious bourgeoisie, slaughtered peasants and uprooted civilians - all recalled the criticisms of domestic actors and conditions during the First World War. ${ }^{78}$ In this sense, criticism was not contained.

The tendentious humour of war threatened constantly to spill over into civilian life. The two worlds - military and civilian - were intended to be separate, but the latter was menaced by the former during the twentieth century. 
'Krieg und Frieden', appearing in Der Wahre Jacob in 1915, showed civilians cheering a man who had just saved an infant from drowning in a city river, under the newspaper headline 'A Death Prevented!'; the picture below it depicted a torpedoed 'enemy warship', which had 'sunk with all of its crew', under the headline 'A Glorious Success!'79 The cartoon not only criticized the fickle sensationalism of newspapers but also exposed the double standard of wartime morality, questioning the idea that military killings were glorious or even justified. Civilians' views of combat were trivial, proclaimed 'Der Schützengraben in Westend', commenting on a report that a trench had been constructed on the outskirts of Berlin as a public spectacle, with an entry fee of fifty pfennig. ${ }^{80}$ In the cartoon the rentier Müller declares, 'So that is exactly what it is like out there on the battlefield', to which Frau Müller replies, 'Yes, yes, now I understand. There's only one thing I don't understand: where do our field-greys get their fifty pfennig from each time they want to go in their trenches?' The image portrays a real infantry unit passing through the turnstile and cleaning their boots before entering the showground trench, with its helpful display signs and its actorinhabitants. Given the grisly reality of the war, such civilian misunderstanding and ignorance were deeply resented, as a series of caricatures of the well-meaning but bloody-handed pacifist Woodrow Wilson evinced. ${ }^{81}$ 'Eine neue Note Wilsons an Deutschland!' (1915) portrayed a rich, arrogant-looking American family standing on the parapet of a British trench, their child waving a stars-and-stripes flag at the soldiers opposite: 'We would understand it to be a fundamentally unfriendly act if shots were to be fired from German positions on English trenches whilst these were being visited by friendly American travel companies,' ran Wilson's 'note'. 82 Other cartoons almost rejoiced at the 'fact' that gullible American tourists were allegedly being used by Britain during the First World War to protect its shipping from U-boat attacks. ${ }^{83}$ Civilians, it was implied, could be callous by omission, ignoring and profiting from the killing of the fighting front. Death itself was often represented as a civilian burgher or businessman cashing in on the pointlessly rising toll of casualties. 'Mors triumphator', published by Simplicissimus in the spring of 1918, imagined a cigar-smoking skeleton in black tie, relaxing in a comfortable armchair, above the caption, 'The greatest beneficiary of war remains tax-free.' 84 By the later stages of the First World War and, it could be held, throughout the Nazi era, war constantly threatened to come home. One cartoon in 1918 confronted the 'Heimatfront' with a street of destroyed buildings extending to the horizon behind a stooped, grieving mother: 'Wake up and look at the war - will it look like this at home?'85 Even the sacred country idyll of Germany - and of Europe - looked likely to succumb to the imperatives of military conflict, with one caricature in 
Simplicissimus in February 1918 summoning up the prospect of Europeans as cave dwellers 'after the fifteenth year of war', and others in the same publication and in Der Wahre Jacob in 1919 displaying Deutscher Michel emaciated and naked on the snowy edge of a cold and dark forest. ${ }^{86}$

Horrifying images of war menaced combatants and civilians alike, irrespective of which side they were on, undermining the enforcement of domestic norms and codes of behaviour, and releasing uncontrollable fears and other emotions. The more demonic cartoonists' representations of Germany's enemies and of war itself were, the greater the menace appeared to be. Thus, when Napoleon I was depicted sitting unaffected amongst Hydras, lions and wolves, figures of death and skulls (as 'Der grosse Todtengräber'), or amidst the freshly killed carrion of the battle of Leipzig in 1813 (in 'Das grosse Rabengastmahl bei Leipzig'), it was apparent to readers that the soldiers of the German states were the likely victims. ${ }^{87}$ Similarly, when Kladderadatsch warned on its front page in November 1870 that 'Der Russe kommt!' or Simplicissimus sarcastically labelled illiterate, gross-featured, big-boned, bear-like Russian soldiers 'Die Mithüter der Kultur' at the end of 1914, the intention was not only to mock the Russians but to warn German citizens. ${ }^{88}$ Depictions in Der Wahre $J a c o b$ in 1915 of Genghis Khan and the Cossacks riding into a German village, unaware - unlike the reader of the magazine - of a German grandmother and child in a womb-like dwelling beside them, their swords raised and their mouths screaming for blood, or later Nazi representations of a Soviet beast, unleashed on Europe by the Allies and rushing straight at the viewer, were unlikely to reassure the cartoons' German readership. ${ }^{89}$ War was monstrous, and its victims faceless. It was not merely the Social Democratic Der Wahre Jacob during the First World War which imagined the figure of death congratulating himself on having signed 'such a good business contract', various versions of which were hanging on the wall, at the expense of 'Russians, Frenchmen, Englishmen, Germans, Montenegrins, and Serbs'; a liberal magazine such as Simplicissimus could just as easily display death as a skeleton, with his head in his hands, on a battlefield of corpses in Flanders: 'Humanity, stop - I can take no more!'9o The victims of death, like the mountain of skulls created for money by Britain in 'Der britische Unterstand', were just as likely to be Germans as members of other nationalities, as were the victims of hunger - withered corpses - in 1919 and 1939, as a result of Allied reparations and an American blockade. ${ }^{11}$ War, in some cartoons of the twentieth century, was literally a monster, indiscriminate, ruthless and purposeless: bestial and gigantic as 'Das Kriegsgespenst' (1916) amongst innocent children of the future, pledging unconvincingly 'not to touch them'; a reptilelimbed globe in 'Wir und die Welt' (1917); and an amorphous, dinosaur-sized 
moloch, chewing its way through a mass of defenceless, naked bodies in 'Sowjetrussische Aufrüstung' (1936).92 As a machine, war could be deployed by Germany - as in 'Patentdiebstahl der Deutschen' (1915), which envisaged a huge German-manufactured textile machine consuming the crowd before it - or it could be used by Germany's enemies, but its victim seemed to be humanity as a whole. 93

In such circumstances, wartime humour appeared - by the twentieth century - to play the disciplinary role ascribed to it by Billig only in an unreliable fashion. Certainly, cartoons continued to warn of external enemies and the dangers of doubting or abandoning the national cause. However, they also hinted at the unbridled nature of warfare and the overturning of all moral norms, not merely existing ones, in favour of better alternatives. Much caricature - perhaps the majority of cartoons in the two world wars - appears to have played a similar role to that of certain works of art and literature, underlining the horror of war rather than creating a comic counter-world.

\section{Conclusion}

Twentieth-century warfare upset the usual subversive and disciplinary functions of humour. In wartime there was a discernible shift from the ridiculing of authorities at home, by means of incongruous juxtaposition and comparison, to the demonization of enemies and the maintenance of group solidarity through the identification of external foes, who became the butt of jokes. The shift was accompanied by experimentation with the existing symbols and traditions of caricature, as cartoonists attempted to imagine the horrors of war. Their principal mode of representation was 'black humour', which can be understood not merely as the humour of the gallows - or the cheating of death - but as humour deriving from a confrontation with suffering or death, as either a victim or a perpetrator. 94 The strong emotions provoked by war were difficult to control. The British journalist and writer Philip Gibbs, commenting on the First World War, noted that contemporaries 'shouted with laughter', 'the more revolting it was', because it had become obvious that 'civilization', which had taught 'that the whole object of life was to reach out to beauty and love, and that mankind, in its progress to perfection, had killed the beast instinct, cruelty, blood-lust, the primitive, savage law of survival by tooth and claw and club and axe', was false, 'broken like a china vase dashed to the ground'. 95 'The war-time humour of the soul roared with mirth at the sight of all that dignity and elegance despoiled', he concluded, in the bitter but also lustful 'laughter of mortals at the trick which had been played on them by an ironical fate'. ${ }^{6}$ Whereas the proximity of death and the experience of social solidarity during wars seemed to bring industrial societies closer to elemental 
forms of 'collective consciousness', the extraordinary and extreme nature of such feelings proved fragmentary. 97

Caricatures, jokes, stories in trench newspapers and even pantomimes and cabaret took on a regular form, of course, combining 'gallows' and 'brave' humour and working to bolster morale. ${ }^{98}$ Jokes were also used to press young men into volunteering, to prevent desertion and to police and criticize the behaviour of adolescents and women. 99 Wartime cartoons, though, rarely functioned in such a manner, even though the caricaturists of Simplicissimus had managed by the early twentieth century to establish the tradition of visual commentary on social mores in peacetime. ${ }^{100}$ The absence of the main staple of satire - namely attacks on political personalities and institutions - transformed the role of caricature. It proved difficult under conditions of censorship (or self-censorship during the Franco-German and First World Wars) for satirical publications to comment on current affairs as they happened, depriving them of the actuality on which their humour relied and leaving it up to literature and art (especially within the Dada movement) to expose the absurdity and suffering of war. ${ }^{101}$ All the same, nihilistic satire, which seemed to revel in or revile destruction for its own sake, continued to play an important part in twentieth-century politics, having been granted permission - which was regularly revoked - to reveal the workings and consequences of violence, revelations that were still prohibited in other, more realistic visual media. 
${ }^{1}$ Ernst Gombrich, Art and Illusion: A Study of the Psychology of Pictorial Representation (London: Phaidon, 1962), p. 290.

${ }^{2}$ Ludwig Hollweck, Karikaturen: Von den Fliegenden Blättern zum Simplicissimus 1844-1914 (Munich: Süddeutscher Verlag, 1973), pp. 169-70.

${ }^{3}$ The success of Die Gartenlaube, which was the most popular periodical of the 1860s, 1870s and 1880s and the pioneer of lithographs, and of the Illustrierte Zeitung, which in the 1900s became the first newspaper to sell more than one million copies per issue through the extensive use of photographs, bore witness to the popularity of images. In comparison, the circulation figures of satirical magazines such as Simplicissimus $(100,000)$, Kladderadatsch $(85,000)$, Ulk $(70,000)$, Lustige Blätter $(100,000)$ and the Social Democratic Der wahre Jacob $(160,000)$ were gradually being overshadowed by those of such 'realistic' publications but nevertheless remained high.

${ }^{4}$ Patrick Merziger, 'Humour in Nazi Germany: Resistance and Propaganda? The Popular Desire for an All-Embracing Laughter', International Review of Social History, 52 (2007), pp. 275-90. It goes without saying that the conditions of political expression, cultural production and censorship (and self-censorship) were fundamentally different in Germany during the wars of unification, the First World War and - under the repressive conditions of the National Socialist dictatorship - the Second World War. Despite these differences, some marked similarities in the actual content of wartime cartoons exist. I examine these here. ${ }^{5}$ Quoted in Ann Taylor Allen, Satire and Society in Wilhelmine Germany: Kladderadatsch and Simplicissimus, 1890-1914 (Lexington: University Press of Kentucky, 1984), p. 11.

${ }^{6}$ Studies of 'German ideology' in wartime are now common: Michael Jeismann, Das Vaterland der Feinde (Stuttgart: Klett-Cotta, 1992); Roland Stromberg, Redemption by War: The Intellectuals and 1914 (Lawrence: Regents Press of Kansas, 1982); Sven Oliver Müller, Die Nation als Waffe und Vorstellung: Nationalismus in Deutschland und Grossbritannien im Ersten Weltkrieg (Göttingen: Vandenhoeck \& Ruprecht, 2002); Wolfgang J. Mommsen (ed.), Kultur und Krieg (Munich: Oldenbourg, 1998); Klaus Schwabe, Wissenschaft und Kriegsmoral (Göttingen: Musterschmidt, 1969); and David Welch, Germany, Propaganda and Total War, 1914-1918 (New Brunswick, NJ: Rutgers University Press, 2000).

${ }^{7}$ See especially Martina Kessel, 'Laughing about Death? "German Humour" in the Two World Wars', in Paul Betts et al. (eds), Between Mass Death and Individual Loss: The Place of the Dead in Twentieth-Century Germany (New York: Berghahn Books, 2008), pp. 197-218; and Martina Kessel, 'Talking War, Debating Unity: Order, Conflict, and Exclusion in "German Humour" in the First World War', in Martina Kessel and Patrick Merziger (eds), The Politics of Humour: Laughter, Inclusion, and Exclusion in the Twentieth Century (Toronto: University of Toronto Press, 2012), pp. 82-107.

${ }^{8}$ On the functioning of atrocity stories, see especially John Horne and Alan Kramer, German Atrocities, 1914: A History of Denial (New Haven, CT: Yale University Press, 2001). 
${ }^{9}$ Pierre Purseigle, 'Mirroring Societies at War: Pictorial Humour in the British and French Popular Press during the First World War', Journal of European Studies, 31 (2001), pp. 289-328, shows how such moral policing occurred in the United Kingdom and France.

${ }^{10}$ See the works of Christie Davies: The Mirth of Nations (New Brunswick, NJ: Transaction, 2002), Jokes and their Relation to Society (Berlin: Mouton de Gruyter, 1998), and Ethnic Humour around the World: A Comparative Analysis (Bloomington: Indiana University Press, 1990).

${ }^{11}$ Peter L. Berger, Redeeming Laughter: The Comic Dimension of Human Experience (Berlin: Walter de Gruyter, 1997), p. 157.

${ }^{12}$ Hermann Sinsheimer, cited in Eugen Roth, Simplicissimus: Ein Rückblick auf die satirische Zeitschrift (Hanover: Fackelträger, 1954), p. 42.

${ }^{13}$ This study is based on specifically satirical magazines for the most part. Cartoons did, of course, occur in other publications across the political spectrum. In most cases, though, innovations and shifts occurred first - or with particular salience - within satirical magazines.

${ }^{14}$ Sigmund Freud, Der Witz und seine Beziehung zum Unbewussten, in Anna Freud (ed.), Gesammelte Werke (London: Imago, 1940), vol. 6, p. 269; see also John Carey's excellent Introduction to Sigmund Freud, The Joke and Its Relation to the Unconscious (London: Penguin, 2002), and Tobias Doring, 'Freud about Laughter - Laughter about Freud', in Manfred Pfister (ed.), A History of English Laughter (Amsterdam: Rodopi, 2002), pp. 121-136.

${ }^{15}$ Sigmund Freud, quoted in Michael Billig, Laughter and Ridicule: Towards a Social Critique of Humour (London: Sage, 2005), p. 154.

${ }^{16}$ I have written more extensively about theories of satire and caricature in Mark Hewitson, 'Black Humour: Caricature in Wartime', Oxford German Studies, 41 (2012), pp. 213-35.

${ }^{17}$ See the extensive series of cartoons in William A. Coupe, German Political Satires from the Reformation to the Second World War (New York: Kraus International, 1987-93), vols 2-3.

${ }^{18}$ Kladderadatsch, October 1914, reproduced in Ingrid Heinrich-Jost (ed.), Kladderadatsch: Die Geschichte eines Berliner Witşblattes von 1848 bis ins Dritte Reich (Cologne: Leske, 1982), p. 119.

${ }^{19}$ Kladderadatsch, 19 July 1942 and 14 February, 28 February and 7 March 1943, reproduced in Heinrich-Jost, Kladderadatsch, pp. 215, 218, 220, 222.

${ }^{20}$ Coupe, German Political Satires, vol. 2, pp. 284, 286, 295-6, and 'Napoleons Traum', p. 285.

${ }^{21}$ Ibid. p. 294.

${ }^{22}$ On animal 'characters' in caricature, see Gombrich, Art and Illusion, pp. 330-58.

${ }^{23}$ Allen, Satire and Society, pp. 131-2.

${ }^{24}$ On Britain as a vampire bat, see 'Marianne und der englische Vampyr', Kladderadatsch, 23 April 1916; as a spider, 'Die englische Spinne', Jugend, 27 October 1914.

${ }^{25}$ Mark Hewitson, National Identity and Political Thought in Germany: Wilhelmine Depictions of the French Third Republic, 1890-1914 (Oxford: Oxford University Press, 2000); Matthew Stibbe, German Anglophobia and the Great War, 1914-1918 (Cambridge: Cambridge University Press, 2001); Vejas G. Liulevicius, The German Myth of the East (Oxford: Oxford University Press, 
2009); and Gerwin Strobl, The Germanic Isle: Nari Perceptions of Britain (Cambridge: Cambridge University Press, 2000).

${ }^{26}$ Kladderadatsch, 11 and 25 July 1915, 13 April 1941; Simplicissimus, 17 December 1941;

Kladderadatsch, 12 July 1942, 29 November 1942, 21 February 1943; and Simplicissimus, 17

December 1941, 29 March 1944.

${ }^{27}$ Kladderadatsch, 23 December 1917.

${ }^{28}$ Ludwig Thoma, Erinnerungen (Munich: Langen, 1931), pp. 185-6.

${ }^{29}$ Quoted in Hollweck, Karikaturen, p. 165.

${ }^{30}$ Quoted in Allen, Satire and Society, pp. 31-2.

${ }^{31}$ Hauptmann, quoted in Hollweck, Karikaturen, p. 172.

32 Simplicissimus, 29 Oct. 1898, in, 1898, in Hollweck, Karikaturen, p. 173.

33 Simplicissimus, no. 34, in Hollweck, Karikaturen, p. 170.

${ }^{34}$ Lesley Milne, 'Letting Loose the Doggerel of War: Humorous and Satirical Journals in Britain, France and Germany, 1914-1918', in Elisabeth Cheauré and Regine Noheijl (eds), Humour and Laughter in History: Transcultural Perspectives (Bielefeld: Transcript, 2014), pp. 59-78; and Lesley Milne, Laughter and War: Humorous-Satirical Magazines in Britain, France, Germany and Russia, 1914-1918 (Newcastle-upon-Tyne: Cambridge Scholars, 2016).

35 Thoma, Erinnerungen, p. 190.

${ }^{36}$ Hermann Sinsheimer, reporting Heine’s comments, in Roth, Simplicissimus, p. 44.

${ }^{37}$ Freud, Witr, p. 109.

${ }^{38}$ Ibid. p. 110.

${ }^{39}$ Mary Douglas, Implicit Meanings, 2nd edn (London: Routledge, 1999), pp. 146, 150; see also Henri Bergson, Laughter: An Essay on the Meaning of the Comic (London: Macmillan, 1911), pp. 8-22, 29-36. Bergson's Le Rire was first published in 1899.

${ }^{40}$ Douglas, Implicit Meanings, p. 150.

${ }^{41}$ Ibid. pp. 152, 150.

${ }^{42}$ Ibid. p. 158.

${ }^{43}$ See, in general, Eberhard Demm, 'Propaganda and Caricature in the First World War', Journal of Contemporary History, 28 (1993), pp. 162-92; Eberhard Demm, Der Erste Weltkrieg in der Karikatur (Hannover: Fackelträger, 1988); and Karl-Heinz Bremm, Propaganda im Ersten Weltkrieg (Darmstadt: Theiss, 2013).

${ }^{44}$ Kladderadatsch, 9 July 1865.

${ }^{45}$ Kladderadatsch, 15 July 1866.

${ }^{46}$ Freud, Witr, p. 114.

${ }^{47}$ Ibid. pp. 114-15.

${ }^{48}$ Allen, Satire and Society, pp. 53-63.

${ }^{49}$ Coupe, German Political Satires, vol. 2; see also, 'Der Judaskuss', Kladderadatsch, 9 August 1914; '500 Jahre Hohenzollern (1415-1915)', Lustige Blätter, 9 October 1914; 'Platz in der Sonne', Lustige Blätter, 12 April 1917; and 'Wilhelm der Reiche’, Ulk, 27 September 1914. 
${ }^{50}$ Simplicissimus, 5 February 1933; and Kladderadatsch, 9 April 1933.

${ }^{51}$ A good example is 'Den verspäteten Friedenstiftern', Kladderadatsch, 28 August 1870, which showed John Bull, a Prussian soldier, the pope, Napoleon III and Victor Emmanuel II.

${ }^{52}$ Kladderadatsch, 21 August 1870.

${ }^{53}$ Coupe, German Political Satires, vol. 2, 46.

${ }^{54}$ Berliner Wespen, 15 July 1870, in Ursula E. Koch, Teufel in Berlin. Illustrierte politische Wit_blätter einer Metropole 1848-1890 (Berlin: C. W. Leske, 1991), p. 483.

${ }^{55}$ Woodrow Wilson was a partial exception, being ridiculed for his false humanitarianism, especially before the United States entered the war: Kladderadatsch, 29 August 1915.

56 Thoma, Erinnerungen, pp. 253-4.

${ }^{57}$ Kladderadatsch, 20 September 1914.

${ }^{58}$ Kladderadatsch, 21 March 1943.

${ }^{59}$ Douglas, Implicit Meanings, p. 152.

${ }^{60}$ Billig, Laughter and Ridicule; on the negotiation and enforcement of norms, see Erving Goffman, Interaction Ritual (New York: Doubleday, 1967).

${ }^{61}$ See especially Norbert Elias, The Civilizing Process: Power and Civility, 2 vols (New York: Basil Blackwell, 1978-82); also Rowland S. Miller, Embarrassment (New York: Guilford, 1996); and Thomas J. Scheff, Microsociology: Discourse, Emotion and Social Structure (Chicago: University of Chicago Press, 1990), Emotions: The Social Bond and Human Reality (Cambridge: Cambridge University Press, 1997), and 'Shame and the Social Bond: A Sociological Theory', Sociological Theory, 18 (2000), pp. 84-99.

${ }^{62}$ Billig, Laughter and Ridicule, p. 7.

${ }^{63}$ Sydney Smith, Elementary Sketches of Moral Philosophy (New York: Harper \& Brothers, 1864), quoted in Billig, Laughter and Ridicule, p. 195.

${ }^{64}$ Pascal, quoted in Berger, Redeeming Laughter, p. 14.

${ }^{65}$ Billig, Laughter and Ridicule, pp. 120-1.

${ }^{66}$ Anton Zijderveld, quoted in Berger, Redeeming Laughter, p. 78.

${ }^{67}$ Lustige Blätter, 23 January 1915; Der Wabre Jacob, 30 April 1915.

${ }^{68}$ Ulk, 13 September 1914.

${ }^{69}$ Jugend, 26 August 1916; Lustige Blätter, 8 July 1916.

${ }^{70}$ Der Stürmer, 4 March 1943.

${ }^{71}$ For instance 'Hass den deutschen Wiegen' and 'Denkt daran', Der Stürmer, 15 October 1942 and 30 October 1941, respectively, which showed a mother rocking a cradle and an injured blond-haired soldier looking contemptuously past a suspicious-looking Jew, with a Stablhelm-summited mountain behind.

${ }^{72}$ Clémentine Tholas-Disset and Karen A. Ritzenhoff (eds), Humour, Entertainment, and Popular Culture during World War I (New York: Palgrave, 2015); and Steffen Bruendel, Zeitenwende 1914: Künstler, Dichter und Denker im Ersten Weltkrieg (Munich: Herbig, 2014). 
${ }^{73}$ Simplicissimus, 1 December 1914; and Jugend, 20 December 1916. See also Jean-Louis

Robert, 'The Image of the Profiteer', in Jean-Louis Robert and Jay Winter (eds), Capital Cities at War: Paris, London, Berlin, 1914-1919 (Cambridge: Cambridge University Press, 1997), vol.

1, pp. 104-32.

${ }^{74}$ Simplicissimus, 15 May 1917; Jugend, 4 February 1918; Der Wabre Jacob, 15 February 1918 and 29 October 1915.

${ }^{75}$ Jugend, 18 July 1917; Kladderadatsch, 29 July 1917.

${ }^{76}$ Simplicissimus, 17 August 1917; Kladderadatsch, 15 December 1918.

${ }^{77}$ Lustige Blätter, 11 March 1916; Ulk, 3 October 1916; and Simplicissimus, 27 June 1916.

${ }^{78}$ Kladderadatsch, 15 December 1940, 16 March and 13 April 1941, 28 March 1943;

Simplicissimus, 25 August 1940; Der Stürmer, October 1936.

${ }^{79}$ Der Wabre Jacob, 2 April 1915.

${ }^{80}$ Lustige Blätter, 29 May 1915.

${ }^{81}$ Ulk, 31 December 1915; Jugend, 27 December 1916 and 4 November 1918; Kladderadatsch, 11 February 1917, 20 May 1917, and 6 October 1918; Simplicissmus, 20 February 1917; and Der Wabre Jacob, 2 August 1918.

${ }^{82}$ Jugend, 7 August 1915.

${ }^{83}$ For instance Jugend, 16 January 1916.

${ }^{84}$ Simplicissimus, 14 May 1918.

${ }^{85}$ Jugend, 7 October 1918.

${ }^{86}$ Simplicissimus, 5 February 1918 and 31 December 1918; and Der Wabre Jakob, 11 April 1919.

${ }^{87}$ Reproduced in Coupe, German Political Satires, vol. 1, pp. 249-50.

${ }^{88}$ Kladderadatsch, 20 November 1870; and Simplicissimus, 22 December 1914.

${ }^{89}$ Der Wabre Jacob, 19 March 1915; and Kladderadatsch, 14 February 1943.

${ }^{90}$ Der Wabre Jacob, 9 January 1915; and Simplicissimus, 19 June 1917.

${ }^{91}$ Simplicissimus, 7 November 1916; and Kladderadatsch, 22 January 1939.

${ }_{92}$ Kladderadatsch, 28 May 1916; Jugend, 28 April 1917; Simplicissimus, 6 September 1936.

${ }^{93}$ Jugend, 21 August 1915.

${ }^{94}$ Berger, Redeeming Laughter, pp. 117-18, gives a much narrower definition of so-called black humour as the humour of the gallows, which defies the tragic, in contrast to tragicomedy, which suspends it, and grotesque humour, which absorbs it.

${ }^{95}$ Philip A. H. Gibbs, Now it Can be Told (New York: Harper \& Brothers, 1920), p. 131. ${ }^{96}$ Ibid. p. 131.

${ }^{97}$ Emile Durkheim, The Division of Labour in Society (Basingstoke: Palgrave Macmillan, 2013); and Emile Durkheim, The Elementary Forms of Religious Life (Oxford: Oxford University Press, 2008).

${ }^{98}$ See, for instance, Stéphane Audoin-Rouzeau, Men at War, 1914-1918: National Sentiment and Trench Journalism in France during the First World War (Oxford: Berg, 1992); and J. G. Fuller, 
Troop Morale and Popular Culture in the British and Dominion Armies, 1914-1918 (Oxford:

Clarendon, 1990).

${ }^{99}$ For more on this, see Roger Chickering, Imperial Germany and the Great War, 1914-1918

(Cambridge: Cambridge University Press, 1998), pp. 95-131.

100 This tradition itself built on much longer-standing social commentary via comic characters such as David Kalisch's Müller and Schulze, or Prudelwitz and Strudelwitz, in Kladderadatsch. ${ }^{101}$ Marc Dachy, Dada: The Art of Revolt (London: Thames \& Hudson, 2006); Dietmar Elgen, Dadaism (Cologne: Taschen, 2015); and R. Bruce Elder, Dada Surrealism and the Cinematic Effect (Waterloo, ON: Wilfrid Laurier University Press, 2012), pp. 69-258. For further references to Dada and additional literature, see the introduction of this special issue. 